\begin{tabular}{l|l} 
Potaice & e-ISSN: 2655-9404 p-ISSN: 2721-8376 \\
Vol. 3 No. 1, Februari 2020 & DOI: 10.20473/ntr.v3i1.17781 \\
\hline
\end{tabular}

Article history: Submitted 3 January 2020 ; Accepted 15 January 2020; Available online 1 February 2020.

\title{
Peranan Desa Wongsorejo Dalam Penyelenggaraan Perlindungan Hak Anak
}

\author{
Dwi Rahayu Kristianti, Zendy Wulan Ayu, W.P. \\ dan Ekawestri Prajwalita Widiati \\ dwi.rahayu@fh.unair.ac.id \\ Universitas Airlangga
}

\begin{abstract}
This article is an output of community service activities under the title Wongsorejo Village Assistance in the Implementation of the Community-Based Integrated Child Protection Program (PATBM) which was carried out in 2019. The community service program was carried out in Wongsorejo Village, Banyuwangi. This village was chosen because the community is just started to have an awareness of the importance of children's rights. Furthermore, efforts to protect and fulfill children's rights in the village are still not integrated. Whereas in 2016, the Ministry of Women's and Children's Empowerment issued a Community-Based Integrated Child Protection Program (PATBM) guideline. The form of community service activities is assistance to the people of Wongsorejo Village in the implementation of the Community-Based Integrated Child Protection Program (PATBM) starting from the stage of the socialization of children's rights to the community up to the preparation of an integrated child protection model involving the participation of children and village communities. For the outcomes to be achieved in this activity are the publication of scientific journals and print media, as well as the preparation of child protection model in accordance with the aspirations of children and village communities. This leads to child-friendly villages that guarantee the fulfillment of children's rights and are oriented to the best interests of children.

Keywords: Children's rights; PATBM; Wongsorejo
\end{abstract}

\begin{abstract}
Abstrak
Artikel ini adalah merupakan luaran dari kegiatan pengabdian masyarakat dengan judul Pendampingan Desa Wongsorejo Dalam Pelaksanaan Program Perlindungan Anak Terpadu Berbasis Masyarakat (PATBM) yang dilaksanakan pada tahun 2019. Program pengabdian masyarakat dilaksanakan di Desa Wongsorejo, Banyuwangi. Desa ini dipilih karena mengingat bahwa masyarakat baru mulai memiliki kesadaran akan pentingnya hak anak. Lebih lanjut, upaya perlindungan dan pemenuhan hak anak yang dilakukan di desa masih belum terpadu. Padahal di tahun 2016, Kementrian Pemberdayaan Perempuan dan Anak telah mengeluarkan suatu pedoman Perlindungan Anak Terpadu Berbasis Masyarakat (PATBM). Bentuk kegiatan pengabdian masyarakat ini adalah pendampingan kepada masyarakat Desa Wongsorejo dalam pelaksanaan programPerlindungan Anak Terpadu Berbasis Masyarakat (PATBM) mulai dari tahapan sosialisasi hak-hak anak kepada masyarakat sampai dengan penyusunan model perlindungan anak terpadu dengan melibatkan partisipasi anak dan masyarakat desa. Untuk luaran yang ingin dicapai dalam kegiatan ini adalah publikasi jurnal ilmiah dan media cetak, serta penyusunan model perlindungan anak sesuai dengan aspirasi anak dan masyarakat desa. Hal ini untuk menuju desa ramah anak yang menjamin terpenuhinya hak-hak anak dan berorientasi pada kepentingan terbaik bagi anak.
\end{abstract}

Kata Kunci: Hak Anak; PATBM; Wongsorejo. 


\section{Pendahuluan}

Pada masa lalu, anak tidaklah dianggap sebagi manusia yang seutuhnya. Anak lebih dianggap sebagai properti bagi orang tua. Anggapan ini membuat beberapa orang tua bersikap sebagai penguasa bagi anaknya, tanpa memberikan kesempatan pada anak untuk dapat menyuarakan apa yang menjadi kehendaknya. Sejarah pengakuan terhadap anak telah memiliki jalan yang cukup panjang. Hal ini dimulai ketika pada tahun 1923, seorang tokoh perempuan yaitu Eglantyne Jebb membuat 10 pernyataan hak-hak anak. Dilanjutkan dengan disahkannya pernyataan hak anak tersebut oleh Liga Bangsa-Bangsa (LBB). di tahun 1924. Namun baru kemudian di tahun 1959, pernyataan hak-hak anak tersebut diumumkan oleh Persatuan Bangsa-Bangsa (PBB). Dua puluh tahun kemudian, hak anak menjadi suatu hal yang dirasa lebih penting dengan diputuskannya Hari Anak Internasional pada tanggal 1 Juni 1979. Satu dekade setelahnya, di tahun 1989 Konvensi Hak-Hak Anak (KHA) disahkan oleh Perserikatan Bangsa-Bangsa (PBB). ${ }^{1}$ Di Indonesia, hak anak sendiri adalah merupakan hak konstitusional pasca amandemen kedua dari UUD di tahun 2000. Pasal 28B ayat (2) UUD NRI Tahun 1945 menyatakan bahwa "Setiap anak berhak atas kelangsungan hidup, tumbuh, dan berkembang serta berhak atas perlindungan dari kekerasan dan diskriminasi." Hal ini menunjukkan adanya perhatian yang besar dari Negara untuk menjamin perlindungan hak anak Indonesia.

Jauh sebelum amandemen konstitusi tersebut, sebenarnya pemerintah telah menunjukkan perhatiannya terhadap hak anak. Pasca disahkannya KHA oleh PBB, Indonesia segera meratifikasi KHA tersebut melalui Keppres No. 36 Tahun 1990. Namun setelah 12 tahun diratifikasi, Indonesia baru memiliki UU No. 23 Tahun 2002 tentang Perlindungan Anak yang telah diubah dengan UU No. 35 Tahun 2014 tentang Perubahan Atas Undang-Undang Nomor 23 Tahun 2002 Tentang Perlindungan Anak. Aturan hukum ini diundangkan karena merupakan konsekuensi yuridis dari ratifikasi KHA. KHA dan Undang-Undang Nomor 35

1 Unicef Indonesia, 'Mengenal Hak-Hak Anak' (Unicef Indonesia) <https://www. unicef.org/indonesia/id/01_mengenal_hak_hak_anak.pdf.>. 
Tahun 2014 yang merupakan perubahan atas UU Nomor 23 tahun 2002 tentang Perlindungan Anak, secara tegas menyatakan prinsip dalam mewujudkan pemenuhan hak dan perlindungan anak, yang meliputi hak hidup, tumbuh kembang dan hak partisipasi serta kepentingan terbaik bagi anak. ${ }^{2}$

Hak-hak anak tersebut harus dipenuhi tidak hanya semata-mata untuk hidup dan kelangsungan hidup anak, tetapi juga untuk terwujudnya kepentingan terbaik bagi anak, yang berlaku untuk semua anak, tanpa membeda-bedakan, yang dilaksanakan dengan menghargai pandangan anak. ${ }^{3}$ Namun sayang, pelanggaran atas hak anak masih saja terjadi di berbagai daerah, hal ini terlihat dari masih tingginya kasus kekerasan terhadap anak. Menurut data Sistem Informasi Online Perlindungan Perempuan dan Anak (SIMFONI PPA) selama bulan januari sampai dengan Agustus 2018, korban kekerasan psikis 1.878 anak, korban kekerasan seksual 2.190 anak, korban kekerasan fisik 2.536 anak dan korban penelantaran 649 anak. ${ }^{4}$ Data di atas memunculkan kekhawatiran, utamanya dari Kementrian Pemberdayaan Perempuan dan Perlindungan Anak (KPPPA). Mengacu pada data tersebut, KPPPA mengeluarkan sebuah pedoman Perlindungan Anak Terpadu Berbasis Masyarakat (PATBM) di tahun 2016. PATBM adalah suatu gerakan perlindungan anak yang dikelola oleh sekelompok orang yang tinggal di suatu wilayah (desa/kelurahan). Melalui PATBM, masyarakat diharapkan mampu mengenali menelaah, dan mengambil inisiatif untuk mencegah dan memecahkan permasalahan kekerasan terhadap anak yang ada di lingkungannya sendiri. ${ }^{5}$

2 Kementerian Pemberdayaan Perempuan Dan Perlindungan Anak Republik Indonesia, Press Release Konvensi Hak Anak (KHA) Mewujudkan Karya Nyata Perlindungan Hak Anak Siaran Pers Nomor: B-166/Set/Rokum/MP 01/09/2018, Kemenpppa (online), 17 September 2008, https://www.kemenpppa.go.id/index.php/page/read/29/1862/konvensi-hak-anak-kha-mewujudkan-karya-nyata-perlindungan-hak-anak

3 Kementerian Pemberdayaan Perempuan Dan Perlindungan Anak Republik Indonesia, Pedoman Perlindungan Anak Terpadu Berbasis Masyarakat (PATBM), 2016.

4 Kementerian Pemberdayaan Perempuan Dan Perlindungan Anak Republik Indonesia, Press Release Konvensi Hak Anak (KHA) Mewujudkan Karya Nyata Perlindungan Hak Anak Siaran Pers Nomor: B-166/Set/Rokum/MP 01/09/2018, Op.Cit.

5 Kementerian Pemberdayaan Perempuan Dan Perlindungan Anak Republik Indonesia, Pedoman Perlindungan Anak Terpadu Berbasis Masyarakat (PATBM), Op.Cit, [4-5]. 
Berdasarkan pedoman untuk gerakan PATBM ini, Desa/Kelurahan menjadi wilayah yang disasar untuk pelaksanaan gerakan PATBM. Hal ini dikarenakan pemerintah melihat adanya potensi desa/kelurahan untuk melaksanakan program pemerintah. Desa merupakan struktur kelembagaan negara yang paling dekat dengan masyarakat dan telah mempunyai peran penting dalam perbaikan nasib hidup rakyat. Proses kekuasan yang sentralistik di masa lalu telah melemahkan berbagai potensi (kemampuan) desa, sehingga berbagai bentuk proses dan bentuk kehidupan masyarakat desa yang dibangun dari akar tradisi setempat secara sistematis hilang. Oleh karena itu, sangatlah cocok dirasa bahwa gerakan PATBM ini dilaksanakan di desa/kelurahan. Sejak 2016, PATBM telah diperkenalkan ke masyarakat, namun gaung pelaksanaan masih menjadi tanda tanya. Hal ini dapat dilihat dari permasalahan yang tim pengusulkan di Desa Mitra, yaitu Desa Wongsorejo, Kecamatan Wongsorejo, Kabupaten Banyuwangi, Jawa Timur. Hak anak atas pendidikan dan kesehatan terlihat masih kurang memadai di desa ini.

Terdapat beberapa masalah terkait perlindungan hak anak, diantaranya yaitu biaya sekolah yang mahal, lokasi sekolah yang jauh dari pemukiman warga. ${ }^{6} \mathrm{Hal}$ ini menimbulkan dampak yaitu berakibat pada kualitas pendidikan menurun. Selanjutnya, penurunan kualitas pendidikan ini ternyata juga berkorelasi dengan kualitas kesehatan yang akhirnya menurun. Akibat pendidikan yang kurang, anak-anak di desa terpaksa melakukan perkawinan di bawah umur. Masalah lain muncul akibat dari perkawinan di bawah umur tersebut, yaitu pada masa kehamilan dan proses melahirkan. Letak puskesmas jauh dari pemukiman warga dan kondisi jalan yang sangat buruk membuat proses persalinan menjadi hal yang penuh resiko tinggi bagi ibu-ibu muda di desa. Lebih miris lagi, karena dari ibu-ibu muda ini melahirkan generasi baru yang juga menghadapi permasalahan pelik yang serupa yaitu fasilitas

\footnotetext{
6 Ira Rachmawati, 'Jika Sekolah Murah, Saya Tidak Mau Menikah', Kompas (online), 15 Juli 2015, https://regional.kompas.com/read/2015/07/15/16144631/.Jika.Sekolah. Murah.Saya.Tidak.Mau.Menikah.
} 
pendidikan dan kesehatan yang tidak memadai dikarenakan letak yang jauh dan kondisi jalan yang buruk. Semua hal di atas diawali dengan adanya konflik lahan yang berlarut-larut dalam penyelesaiannya. Ini menyebabkan pembangunan sulit menjangkau ke desa ini. Seperti yang diungkapkan oleh salah aatu warga bahwa "Ditambah lagi konflik lahan yang bertahun-tahun dialami oleh masyarakat Bongkoran sehingga sulit mendapatkan akses pendidikan dan kesehatan" ${ }^{7}$

Beranjak dari permasalahan tersebut, maka tim pengusul berupaya untuk melakukan kegiatan pengabdian kepada masyarakat di Desa Wongsorejo, utamanya di Dusun Bongkoran. Hal yang dilakukan adalah melakukan pendampingan pelaksanaan gerakan PATBM. Pendampingan ini memiliki beberapa tujuan. Pertama, agar masyarakat semakin sadar akan pentingnya hak-hak anak. Kedua, untuk mengidentifikasi problematika dalam upaya perlindungan anak terpadu sehingga dapat ditemukan dan diterapkan jenisjenis perlindungan anak yang sesuai dengan budaya masyarakat desa. Ketiga, untuk membentuk model perlindungan anak terpadu sesuai aspirasi anak dan masyarakat desa. Dengan tujuan tersebut, maka pendampingan ini diharapkan memperoleh hasil yaitu merealisasikan pemenuhan hak-hak anak melalui PATBM.

\section{Metode}

Kegiatan pengabdian masyarakat ini memiliki rancangan kegiatan dan metode dalam pelaksanaannya. Kegiatan ini dirancang dalam bentuk penerjunan langsung para dosen pengusul dan pembicara, dan juga beberapa mahasiswa ke daerah lokasi kegiatan. Kegiatan dilakukan dalam bentuk pendampingan yang akan dilaksanakan menggunakan 3 (tiga) metode:

7 ibid. 


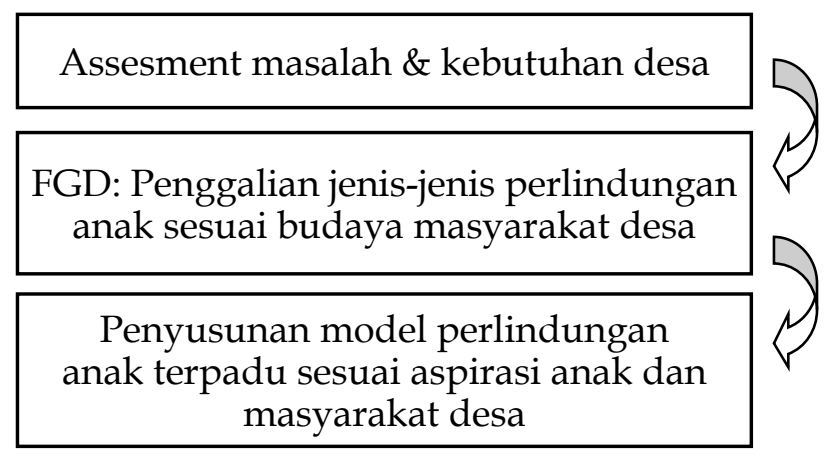

Metode pertama yang digunakan adalah asesmen. Asesmen berasal dari kata berbahasa Inggris yaitu assessment yang memiliki arti penilaian. ${ }^{8}$ Penilaian ini digunakan untuk memperoleh data mengenai permasalahan dan kebutuhan desa yang ada di lokasi kegiatan. Asessment masalah dan kebutuhan desa dilakukan dengan cara datang ke desa berdialog dengan anak-anak, remaja dan masyarakat desa termasuk tokoh masyarakat dan perangkat desa untuk menggali potensi dan masalah dalam perlindungan dan pemenuhan hak anak di desa Wongsorejo.

Metode kedua adalah Fokus Group Discussion (FGD). Menurut Coloumbia dan Hening (1990) mereka mengemukakan bahwa Fokus Grup Discussion adalah wawancara dari sekelompok kecil yang dipimpin seorang narasumber atau moderator yang tugas mereka salah satunya mendorong peserta untuk berani berbicara terbuka dan spontan mengenai hal yang dianggap penting namun berhubungan dengan topik diskusi yang sedang dibahas. ${ }^{9}$ Dalam kegiatan pengabdian masyarakat dilakukan dengan cara mengundang anak dan para wakil masyarakat dari seluruh kelompok untuk menggali jenis-jenis perlindungan anak sesuai budaya masyarakat desa.

Terakhir, metode yang digunakan adalah penyusunan model perlindungan anak terpadu sesuai aspirasi anak dan masyarakat desa. Metode ini dilakukan dengan cara sosialisasi hak-hak anak sesuai ketentuan peraturan perundang-

\footnotetext{
8 Maria Titian Moi Lay, Keterlaksanaan dan Hambatan-Hambatan Asesmen Pendidikan Karakter, Skripsi (Program Sarjana Universitas Sanata Dharma Yogyakarta).[30].

9 Mughnifar Ilham, 'Focus Group Discussion - Definisi, Tujuan, Syarat, Jenis Dan Manfaat, MateriBelajar.co.id (online), https://materibelajar.co.id/focus-group-discussion/, 8 Januari 2020, dikunjungi pada tanggal 2 Februari 2020.
} 
undangan yang berlaku. Dengan kegiatan pendampingan ini, masyarakat diharapkan dapat menyusun suatu model perlindungan anak terpadu berbasis masyarakat yang tentunya sesuai dengan aspirasi anak dan masyarakat desa.

\section{Hasil dan Pembahasan}

\section{a. Assessment Masalah Desa Dengan Perwakilan Organisasi Desa}

Kegiatan Pengabdian kepada Masyarakat ini direncanakan dilakukan dalam bentuk pendampingan. Hal yang dilakukan pertama kali adalah menggali informasi atas aspirasi desa dalam pembentukan model perlindungan hak anak. Assessment dengan perwakilan desa telah dilakukan. Pada kegiatan pertama ini, perwakilan desa yaitu dari Organisasi Petani Wongsorejo Banyuwangi menyampaikan beberapa informasi terkait dengan perlindungan hak anak di desa.

Hal yang menarik untuk dipaparkan dalam laporan ini, yaitu adanya pendapat dari wakil organisasi yang menyatakan bahwa daerah mereka, yaitu Dusun Bongkoran, Desa Wongsorejo, sebagai daerah konflik. Hal ini terjadi karena lahan yang mereka tempati memang masih terdapat permasalahan agraria yang belum dapat teratasi sampai saat ini. Walaupun begitu, warga dusun tetap mendiami dan mengupayakan pertanian di wilayah tersebut dengan berdasar pada pendapat hukum dari Pusat Studi HRLS (Human Rights Law Studies) Fakultas Hukum Universitas Airlangga. Perlindungan hak anak di dusun tersebut dapat dikatakan belum cukup memadai. Dalam kegiatan ini, tim pengabdian kepada masyarakat Departemen Hukum Tata Negara Fakultas Hukum Universitas Airlangga melihat hanya pada 2 (dua) aspek hak anak, yaitu hak atas pendidikan dan hak atas kesehatan.

Menurut informasi yang kami dapat, pada saat ini masih belum ada pusat pelayanan terpadu untuk perlindungan hak anak ini. Padahal saat ini, warga desa melalui perwakilannya mengharap segera terbentuk pusat layanan bagi hak anak. Hal ini mengingat bahwa hak atas penddikan dan hak atas kesehatan bagi anakanak merupakan hak yang mendasar. Hal lain yang juga didapat dari assessment ini adalah adanya masalah-masalah yang menjadi hambatan dalam pelaksanaan 


\section{Dwi Rahayu, dkk: Peranan Desa Wongsorejo...}

perlindungan hak anak. Masalah pertama yang menjadi kekhawatiran warga adalah mengenai sekolah. Saat ini hanya terdapat 1 (satu) Sekolah Dasar yang berisi total siswa sekita 125 siswa dan tidak terdapat SMP ataupun SMA di lokasi. Untuk kelanjutan kegiatan belajar mereka ke jenjang yang lebih tinggi, para siswa harus menempuh jarak setidak-tidaknya $10 \mathrm{~km}$ untuk menuju sekolah. Jarak yang jauh dari rumah ke sekolah ini juga tidak ditunjang dengan adanya fasilitas jalan ataupun transportasi umum yang mencukupi. Jalanan desa hanya terbuat dari jalan batu pasir dan kadang kala menemui jalur yang curam dan sulit untuk dilewati, utamanya pada musim hujan. Hal lain yang cukup menghambat, adalah kurangnya kehadiran orang tua dalam upaya anak untuk melanjutkan sekolah. Beberapa warga memilih untuk menjadi Buruh Migran di negara lain untuk memenuhi kebutuhan ekonomi keluarga. Hal ini menyebabkan beberapa anak tidak mendapatkan pengawasan dan bimbingan utuh dari orang tuanya.

\section{b. Focus Group Discussion Dengan Warga Desa}

FGD dilaksanakan pada tanggal 31 Agustus 2019. Pada FGD ini, Kami mengundang warga, Organisasi Petani Wongsorejo Banyuwangi, dan anak-anak warga Desa Wongsorejo. Dalam kegiatan ini, kami menyampaikan beberapa pengantar materi berkaitan dengan perlindungan hak anak baik kepada warga desa dan Organisasi Petani Wongsorejo Banyuwangi maupun kepada anak-anak. Selain itu, Kami juga menghimpun beberapa informasi terkait aspirasi warga dan anak-anak. Kegiatan FGD di bagi menjadi 2 (dua) forum secara bersamaan. Forum pertama terdiri dari warga, Organisasi Petani Wongsorejo Banyuwangi dan beberapa dosen dari Departemen Hukum Tata Negara. Sedangkan Forum kedua terdiri dari anak-anak serta beberapa dosen Hukum Tata Negara.

KegiatanFGD yang dilaksanakan diforum pertama diawali dengan sambutan oleh Bapak Yateno selaku Ketua Organisasi Petani Wongsorejo Banyuwangi. Bapak Yateno memberikan sambutan yang antara lain berisi sambutan selamat datang, pengenalan dosen-dosen dari Departemen Hukum Tata Negara sekaligus pengantar penyampaian maksud kegiatan pada hari tersebut kepada warga dan 
Organisasi Petani Wongsorejo Banyuwangi. Kesempatan kedua diberikan kepada Ibu Dwi Rahayu Kristianti, S.H., MA. selaku Ketua Departemen Hukum Tata Negara untuk menyampaikan rasa terima kasih kepada warga dan Organisasi Petani Wongsorejo Banyuwangi atas diterima nya kegiatan ini untuk diadakan di Desa Wongsorejo. Tidak lupa, Ibu Dwi Rahayu Kristianti, S.H., MA juga menyampaikan harapan-harapan yang akan dicapai dengan diselenggarakannya kegiatan ini.

Setelah sambutan Ketua Departemen Hukum Tata Negara, acara di FGD forum pertama dilanjutkan dengan materi pengantar mengenai perlindungan hak anak yang disampaikan secara bergantian oleh Dr. R. Herlambang Perdana Wiratraman, S.H., MA., Ibu Dwi Rahayu Kristianti,S.H., MA. serta Ibu Zendy Wulan Ayu W.P., S.H., LL.M. Dalam sesi ini, dosen-dosen dari Departemen Hukum Tata Negara tersebut memberikan materi pengantar mengenai siapa yang dimaksud dengan anak, apa saja yang termasuk hak-hak anak, apa pentingnya perlindungan terhadap hak-hak anak, beberapa permasalahan terkait pelanggaran hak anak. Para dosen tersebut memberikan perhatian yang lebih kepada permasalahan yang banyak timbul di Desa Wongsorejo yaitu permasalahan akses terhadap hak atas pendidikan dan kesehatan anak.

Setelah penyampaian materi tersebut, diadakan sesi diskusi dengan harapan bahwa akan lebih banyak aspirasi dari para warga dan Organisasi Petani Wongsorejo Banyuwangi sebagai bahan untuk membuat model perlindungan hak anak sesuai aspirasi warga desa. Mayoritas warga dan Organisasi Petani Wongsorejo Banyuwangi yang hadir pada kegiatan tersebut tidak mengenyam pendidikan dasar sampai selesai. Selain itu, ternyata hal tersebut juga terjadi pada anak-anaknya. Mereka lebih memilih untuk bekerja sebagai petani dan buruh kasar. Faktor kurangnya pemahaman terhadap pentingnya pendidikan sebagai bekal di masa depan bagi anak-anak menjadi faktor yang sangat krusial dalam permasalahan ini. Ketika si anak menyampaikan niat untuk lebih memilih bekerja daripada menyelesaikan sekolahnya adalah merupakan hal yang normal bagi mayoritas para orang tua warga Desa Wongsorejo. 

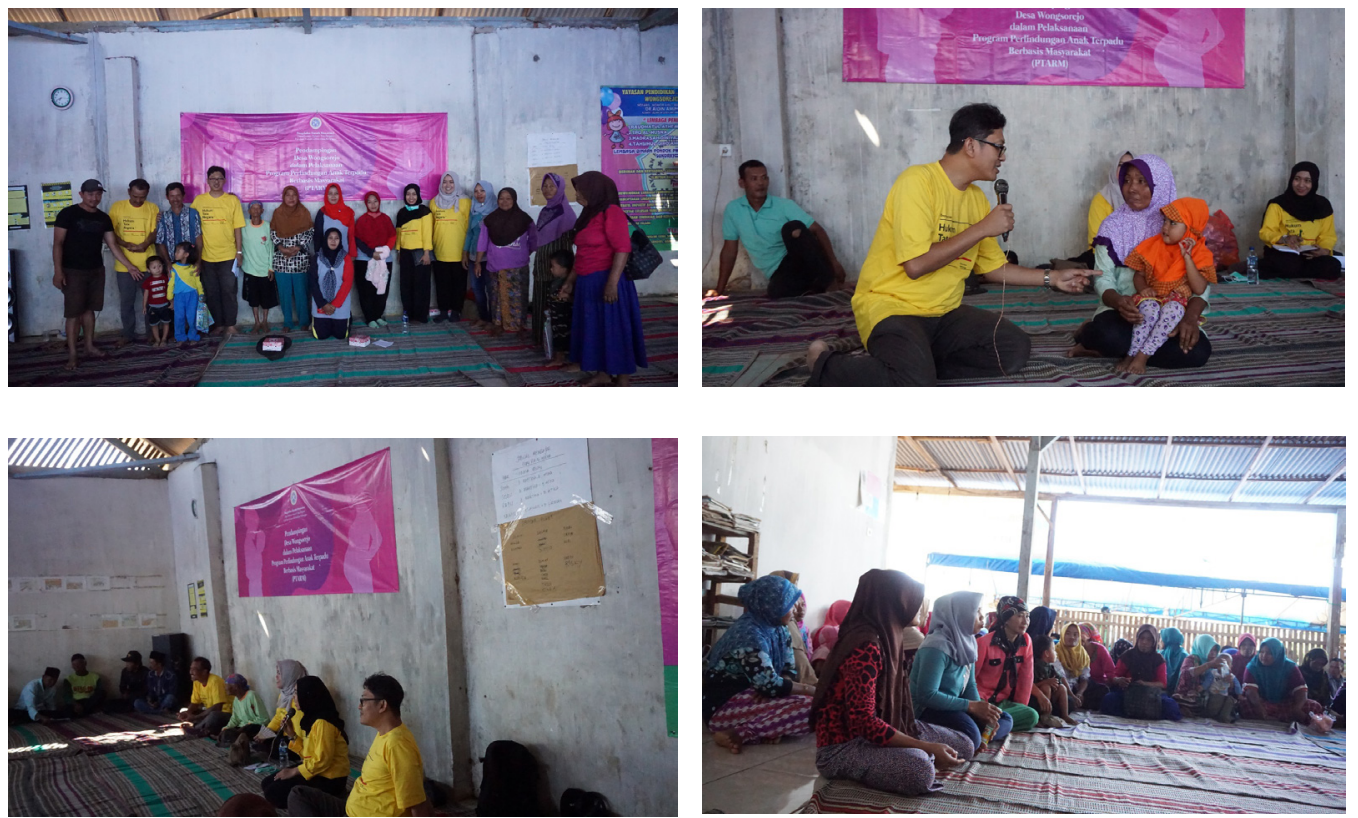

Faktor kurangnya pemahaman terhadap pentingnya pendidikan tersebut di dukung oleh beberapa faktor yang lain sehingga menyebabkan tingginya angka putus sekolah di desa tersebut. Terbatasnya jumlah sekolah dan sulitnya akses menuju ke sekolah tersebut juga turut mempengaruhi keengganan anakanak untuk pergi ke sekolah dan para warga untuk mengantar anaknya ke sekolah. Selain itu, faktor ekonomi juga mendorong para warga agar anakanaknya bisa lebih cepat menghasilkan uang dengan bekerja daripada bersekolah. Rendahnya tingkat pendidikan juga mendorong ke arah banyaknya terjadi kasus perkawinan di usia anak-anak. Ketidaksiapan secara fisik dalam usia yang sangat muda dan kurangnya fasilitas kesehatan yang bisa di akses oleh warga desa menjadi penghambat bagi calon ibu muda yang sedang hamil dan akan melahirkan.

Sedangkan di forum kedua FGD terdapat peserta anak-anak dan beberapa dosen dari Departemen Hukum Tata Negara. Dalam forum kedua tersebut, para dosen mengenalkan kepada anak-anak mengenai hak-hak mereka dengan cara yang mudah dan menyenangkan bagi mereka yaitu melalui beberapa permainan. Dalam acara tersebut, anak-anak sangat antusias mengikuti kegiatan. Dari interaksi antara anak-anak dan para dosen dapat diketahui bahwa anak-anak 
tersebut sangat awam dengan hak-hak mereka, misalnya hak untuk bermain, hak atas pendidikan serta hak atas kesehatan.

\section{c. Model Perlindungan Hak Anak Sesuai Aspirasi Anak Dan Warga Desa}

Pada tahap akhir dari kegiatan pengabdian kepada masyarakat ini, tim berusaha untuk membuat dibuat suatu model perlindungan anak yang terintegrasi berdasar dari aspirasi warga desa. Namun hal ini mendapat kendala yang sangat besar. Masyarakat desa mitra pada saat ini dapat dikatakan masih belum terlalu memahami hak-hak apa saja yang dimiliki oleh anak. Tim pengabdian kepada masyarakat merasa bahwa sosialisasi dan peningkatan kesadaran warga masyarakat desa mitra perlu diupayakan terlebih dahulu, sebelum pada akhirnya mereka dapat memikirkan model perlindungan hak anak apa yang sesuai dengan situasi dan kondisi sosial dan juga budaya masyarakat desa mitra.

Pada saat ini telah berdiri sekolah PAUD/TK yang didirikan atas kerjasama warga desa dengan salah satu yayasan di Kabupaten Bnayuwangi. Dengan adanya sekolah ini, kesadaran warga desa akan pentingnya hak atas pendidikan bagi anak mulai muncul. Dari hasil FGD yang dilaksanakan dengan warga desa, mereka mengharapkan sekolah PAUD/TK yang sudah berdiri dapat terus berjalan. Tim pengabdian kepada masyarakat melihat adanya peluang dari keberadaan PAUD/TK ini nantinya akan dapat bersinergi dengan warga desa dalam program perlindungan hak anak.

Oleh karena itu, pembentukan model perlindungan hak anak belum dapat terbentuk sampai dengan berakhirnya pengabdian kepada masyarakat tahun anggaran 2019. Diharapkan, program pengabdian kepada masyarakat ini dapat dilanjutkan di tahun anggaran 2020 agar model perlindungan hak anak yang diharapkan dapat terwujud.

Selain itu, peningkatan kesadaran masyarakat secara umum terkait pemenuhan hak anak ini juga dilakukan dengan membagikan hasil pengabdian masyarakat dalam bentuk karya ilmiah maupun berita. Hasil tersebut dapat disebutkan sebagai berikut: 
Tabel 1. Tabel Output Kegiatan Pengabdian kepada Masyarakat

\begin{tabular}{|c|c|c|c|}
\hline No & Jenis Luaran & Indikator Capaian & Keterangan \\
\hline 1 & $\begin{array}{l}\text { Publikasi artikel } \\
\text { ilmiah }\end{array}$ & $\begin{array}{l}\text { Terpublikasi artikel } \\
\text { ilmiah pada jurnal } \\
\text { ber ISSN atau } \\
\text { prosiding ber ISBN } \\
\text { dari seminar nasional }\end{array}$ & Artikel \\
\hline 2 & $\begin{array}{l}\text { Publikasi artikel } \\
\text { media massa }\end{array}$ & $\begin{array}{l}\text { Terpublikasi satu } \\
\text { artikel pada media } \\
\text { massa cetak/ } \\
\text { elektronik }\end{array}$ & $\begin{array}{l}\text { LINK BERITA PENGMAS } \\
\text { BANYUWANGI - DEPT HUKUM } \\
\text { TATA NEGARA FH UNAIR } \\
\text { - } \quad \text { http:// fh.unair.ac.id/tata- } \\
\text { negara-fh-unair-dorong- } \\
\text { perlindungan-hak-anak-di- } \\
\text { banyuwangi/ } \\
\text { - } \text { https://www.instagram. } \\
\text { com/p/B2dmS-cFcrB/ } \\
\text { - http://news.unair. } \\
\text { ac.id/2019/09/13/tata-negara- } \\
\text { fh-unair-dorong-perlindungan- } \\
\text { hak-anak-di-banyuwangi/ }\end{array}$ \\
\hline 3 & Video kegiatan & $\begin{array}{l}\text { Terdokumentasi } \\
\text { kegiatan dalam video } \\
\text { pendek yang akan } \\
\text { dipublikasikan pada } \\
\text { media social. }\end{array}$ & $\begin{array}{l}\text { Ada } 2 \text { video kegiatan (link upload } \\
\text { video) }\end{array}$ \\
\hline 4 & $\begin{array}{l}\text { Peningkatan } \\
\text { keberdayaan } \\
\text { mitra }\end{array}$ & $\begin{array}{l}\text { Tersusunnya model } \\
\text { perlindungan } \\
\text { anak terpadu } \\
\text { dengan melibatkan } \\
\text { partisipasi anak dan } \\
\text { masyarakat desa. }\end{array}$ & $\begin{array}{l}\text { Saat ini yang diharapkan oleh mitra } \\
\text { adalah sekolah PAUD/TK yang } \\
\text { sudah berdiri dapat terus berjalan }\end{array}$ \\
\hline
\end{tabular}

\section{Singkatan dan Akronim}

FGD - Focus Group Discussion

HRLS - Human Rights Law Studies

KHA - Konvensi Hak-Hak Anak

KPPPA - Kementrian Pemberdayaan Perempuan dan Perlindungan Anak

LBB - Liga Bangsa-Bangsa 
PATBM - Perlindungan Anak Terpadu Berbasis Masyarakat

PAUD/TK - Pendidikan Anak Usia Dini/Taman Kanak-Kanak

PBB - Persatuan Bangsa-Bangsa

SIMFONI PPA - Sistem Informasi Online Perlindungan Perempuan dan Anak

Tabel dan Gambar

Tabel 1 - Tabel Output Kegiatan Pengabdian kepada Masyarakat

Gambar 1 - Assesment dan Focus Group Discussion Pengabdian Masyarakat

\section{Penutup}

\section{a. Simpulan}

Hak anak adalah merupakan hak konstitusional. Hal ini terbukti dari dinyatakannya perlindungan terhadap hak anak dalam Pasal 28B ayat (2) UUD NRI Tahun 1945. Pengaturan ini mempunyai konsekuensi yuridis munculnya tanggung jawab negara dalam perlindungan, penyebarluasan, dan pemenuhannya. Selain itu, ratifikasi Konvensi Hak Anak (KHA) melalui Keppres No. 36 Tahun 1990 juga memunculkan tanggung jawab negara sebagai Negara Pihak dalam KHA. Pada saat ini, Indonesia telah memiliki UU No. 23 Tahun 2002 tentang Perlindungan Anak yang telah diubah dengan UU No. 35 Tahun 2014 tentang Perubahan Atas Undang-Undang Nomor 23 Tahun 2002 Tentang Perlindungan Anak. Aturan hukum ini diundangkan sebagai bentuk konsekuensi yuridis dari ratifikasi KHA.

Pada tahun 2016, Kementrian Pemberdayaan Perempuan dan Perlindungan Anak (KPPPA) mengeluarkan sebuah pedoman Perlindungan Anak Terpadu Berbasis Masyarakat (PATBM). PATBM adalah suatu gerakan perlindungan anak yang dikelola oleh sekelompok orang yang tinggal di suatu wilayah (desa/kelurahan). Melalui PATBM, masyarakat diharapkan mampu mengenali, menelaah, dan mengambil inisiatif untuk mencegah dan memecahkan permasalahan kekerasan terhadap anak yang ada di lingkungannya sendiri. 
Setelah melalui diskusi dan analisis masalah yang telah dijalani, ditemukan bahwa di daerah yang menjadi lokasi pengabdian kepada masyarakat kali ini ternyata belum terbentuk adanya PATBM. Padahal pemerintah melalui KPPPA mengharapkan agar desa dapat membentuk suatu pusat layanan yang berfungsi untuk menjamin perlindungan hak anak.

\section{b. Saran}

Permasalahan yang ada di lokasi pengabdian masyarakat membuat tim memiliki sebuah usulan perubahan untuk kemajuan desa. Sesuai dengan pedoman PATBM yang telah dikeluarkan oleh KPPPA, maka seyogyanya masyarakat dapat membentuk program PATBM ini yang tentunya disesuaikan dengan keadaan dan asprirasi warga dan anak-anak di desa. Program ini diharapkan dapat mempertahankan dan meningkatkan keberadaan PAUD/ TK yang sudah berdiri agar dapat terus berjalan.

\section{Daftar Pustaka}

\section{Makalah}

Unicef Indonesia, Mengenal Hak-Hak Anak, Unicef Indonesia (online), https:// www.unicef.org/indonesia/id/01_mengenal_hak_hak_anak.pdf

\section{Skripsi}

Lay, Maria Titian Moi, Keterlaksanaan dan Hambatan-Hambatan Asesmen Pendidikan Karakter, Skripsi, Program Sarjana Universitas Sanata Dharma, Yogyakarta.

\section{Laman}

Ilham, Mughnifar, Focus Group Discussion - Definisi, Tujuan, Syarat, Jenis Dan Manfaat, MateriBelajar.co.id (online), 8 Januari 2020, <https:/ / materibelajar. co.id/focus-group-discussion/>, dikunjungi pada tanggal 2 Februari 2020.

Kementerian Pemberdayaan Perempuan Dan Perlindungan Anak Republik Indonesia, Pedoman Perlindungan Anak Terpadu Berbasis Masyarakat (PATBM), 2016.

-----, Press Release Konvensi Hak Anak (KHA) Mewujudkan Karya Nyata 
Perlindungan Hak Anak Siaran Pers Nomor: B-166/Set/Rokum/MP 01/09/2018, Kemenpppa (online), 17 September 2008, <https://www. kemenpppa.go.id/index.php/page/read/29/1862/konvensi-hak-anakkha-mewujudkan-karya-nyata-perlindungan-hak-anak>.

Rachmawati, Ira, "Jika Sekolah Murah, Saya Tidak Mau Menikah", Kompas (online), 15 Juli 2015, <https:/ / regional.kompas.com/read/2015/07/15/16144631/. Jika.Sekolah.Murah.Saya.Tidak.Mau.Menikah>.

How to cite: Dwi Rahayu Kristianti, Zendy Wulan Ayu, W.P., Ekawestri Prajwalita Widiati, 'Peranan Desa Wongsorejo Dalam Penyelenggaraan Perlindungan Hak Anak' (2020) Vol. 3 No. 1 Notaire. 
64 Dwi Rahayu, dkk: Peranan Desa Wongsorejo...

--Halaman ini sengaja dikosongkan-- 